\title{
Effect of slaughter season on postmortem metabolic characteristics of muscle in the dromedary camel (Camelus dromedarius)
}

\author{
Brahim Hamad ${ }^{1,2 *}$, Hebib Aggad', Leyla Hadef ${ }^{1,2}$, Abdelghani Beddada $^{3}$, Bernard Faye $^{4}$ \\ ${ }^{1} \mathrm{Ibn}$ Khaldoun University of Tiaret, Institute of Veterinary Sciences, Laboratory of Hygiene and Animal Pathology, P.O. Box 78 Tiaret, 14000 \\ Tiaret, Algeria, ${ }^{2}$ University of El-Oued, Faculty of Nature and Life Sciences, Department of Agronomy, P.O. Box 789 El-Oued, 39000 \\ El-Oued, Algeria, ${ }^{3}$ Directorate of Agricultural Services, 39000 El-Oued, Algeria, ${ }^{4} \mathrm{CIRAD}$, Campus International de Baillarguet, TA C/112 A, \\ UMR SELMET, 34398 Montpellier, France
}

\section{A B S T R A C T}

\begin{abstract}
The aim of this study was to determine the effect of slaughter season on the postmortem metabolic characteristics of dromedary camel longissimus thoracis (LT) muscle. A total number of thirty male camels (5-7 years old) were included in this work. Ten camels were slaughtered according to season of the year (winter, spring and summer). The samples were analyzed for muscle $\mathrm{pH}$, muscle temperature, electrical conductivity, drip loss (DL), cooking loss $(C L)$ and thawing loss (TL). No significant $(p>0.05)$ effect of slaughter season on muscle $\mathrm{pH}$ and cooking loss was observed. However, slaughter season significantly $(p<0.05)$ influenced the electrical conductivity, muscle temperature, drip loss and thawing loss. All of these parameters were higher $(p<0.05)$ during summer as compared to winter and/or spring seasons. Moreover, several correlations between different studied parameters were reported. In conclusion, these findings indicated that slaughter season had a significant $(p<0.05)$ effect on several postmortem metabolic parameters of camels. Therefore, this study demonstrated that the electrical conductivity late postmortem measurement can be used as a suitable method for the evaluation of camel's meat quality.
\end{abstract}

Keywords: Algeria; Camel; Meat; Season; Slaughter

\section{INTRODUCTION}

The dromedary camel is a potential source of meat in arid and semi-arid areas of the old world (Kadim, 2013). This meat is regarded as good quality product (Kadim et al., 2011; 2014) especially with high protein value (Raiymbeck et al., 2015). Furthermore, the meat demand at world level increased in the human population in relationship to the growing demography and poverty alleviation. In that context, there is an urgent need for valorizing marginal species as camel to provide red meat (Maqsood et al., 2015).

Pre-slaughtering factors are affecting significantly meat quality. Climatic conditions in the preslaughter period, especially those being responsible of stress for animals could be important (Miranda et al., 2009; Marenčić et al., 2012). In addition, seasonal variations of temperature can affect the level of glycogen in muscles after slaughter and their ultimate $\mathrm{pH}$, the two parameters describing the meat quality
(Węglarz, 2010). Excessive excitement, starving or stress caused by extreme temperature can increase the glycolysis, then lead to high postmortem $\mathrm{pH}$ values which could influence the meat quality (Abril et al., 2001; Honkavaara et al., 2003).

In this respect, in Algeria, high daily temperatures can be registered in summer, while in winter the temperature drops low. Such seasonal variability of the environmental conditions during pre-slaughter could act on the meat quality.

Extensive studies have been reported about the effect of slaughter season on meat quality in different species such as rabbit (María et al., 2006), chicken (Bianchi et al., 2007), goat (Kadim et al., 2008b), beef (Weglarz, 2010), lamb (Chulayo and Muchenje, 2013; D’Alessandro et al., 2013; Sanchez-Sanchez et al., 2013) and pig (Correa et al., 2014). However, these aspects were not common for camels. Thus, the objective of the present study was to examine the effect 
of seasonal slaughtering conditions on postmortem metabolic characteristics of muscle in the dromedary camel in Algeria.

\section{MATERIALS AND METHODS}

\section{Study area}

This study was conducted at El Oued municipality slaughterhouse in the South East of Algeria, during the period from January 2015 to September 2015. This region is characterized by a Saharan desert climate type. Seasons are very marked with hot and dry summers where the mean temperature reaches $34{ }^{\circ} \mathrm{C}$ and cold and slightly humid winters where the mean temperature can drop below $17^{\circ} \mathrm{C}$. The average annual rainfall varies between 80 and $100 \mathrm{~mm}$ (period from October to February).

\section{Animals}

Thirty clinically healthy male camels (Camelus dromedarius) 5-7 years old were used in this study. The animals were living under similar conditions of management and diet. These camels were fed with some barley concentrate and dry straw. The animals were exposed to the same preslaughter handling and transportation processes (walking for $2 \mathrm{~km}$ ). The time from farm to slaughterhouse was approximately 1 hour.

After arrival in the slaughterhouse, all animals were placed in the lairage where they stayed 10 to 12 hours. Ten camels were sampled at each season of the year (winter, spring and summer). Animals were slaughtered following routine commercial slaughterhouse method according to Halal procedure. The average carcass weights were 214.3, 255.0 and $226.5 \mathrm{~kg}$ in winter, spring and summer, respectively. Mean values of slaughter temperature were 16.8, 22.2 and $33.5^{\circ} \mathrm{C}$ in winter, spring and summer, respectively.

\section{Samples collection}

Muscle samples were collected immediately post-slaughter from longissimus thoracis (LT) of the left and right carcass sides between the $10^{\text {th }}$ and $13^{\text {th }}$ ribs. Samples were placed in plastic bags and transported within 60 min after slaughtering to the laboratory in an insulated box filled with ice. Then, the samples were stored at $4-6^{\circ} \mathrm{C}$ for 48 hours.

\section{Meat quality measurements $\mathrm{pH}$ and temperature}

The $\mathrm{pH}$ of the longissimus thoracis (LT) muscle was measured at $90 \mathrm{~min}$ and $48 \mathrm{~h}$ (ultimate $\mathrm{pH}$ ) after slaughter using a portable $\mathrm{pH}$ meter (Hanna waterproof $\mathrm{pH}$ meter, Model Hi 99163, Romania) equipped with a penetrating glass electrode and a temperature adjusting probe. Readings were recorded in triplicates for each measurement; the $\mathrm{pH}$ probe and the thermometer were inserted into muscles to a similar depth $(1.5 \mathrm{~cm})$.

\section{Electrical conductivity}

The electrical conductivity (EC) was recorded (in $\mathrm{mS} / \mathrm{cm}$ ) at 90 minutes and 48 hours postmortem with an electrical conductivity meter Model Hanna EC 215 provided with an electrode of the four rings HI 76303.

\section{Drip loss}

The drip loss was determined using the method described by Honikel (1998) and Franco et al. (2011). The drip loss was recorded on meat samples (LT) of each carcass camel, free of external fat and connective tissue. At 48 hours after slaughter, the samples were hung by a nylon cord in a plastic bag, ensuring the meat had no contact with the juice in the bag. The drip loss was expressed as percentage of weight loss after 48 hours of storage at $4{ }^{\circ} \mathrm{C}$ in a refrigerated chamber, from the time of muscle deboning. The drip loss was calculated using the following formula:

Drip loss $\%=[($ weight before storage - weight after 48 hours of storage)/weight before storage] $\times 100$

\section{Cooking loss}

The cooking loss was determined by method as described by Honikel (1998) with slight modifications reported by Kadim et al. (2016). At 48 hours post-slaughter, the samples were placed in polyethylene bag and totally immersed in a water bath at $70^{\circ} \mathrm{C}$ for $90 \mathrm{~min}$. After cooking, each sample was cooled in running tap water for 20 minutes in its exuded fluids and then removed and dried with paper towel. Cooking loss was determined as the difference in weight of sample before and after cooking, and was expressed as a percentage of the weight before cooking by using the following formula:

Cooking loss $\%=[$ (weight before cooking - weight after cooking)/weight before cooking] $\times 100$

\section{Thawing loss}

The thawing loss was determined by method as described by El-Rammouz et al. (2004). Fourty-eight hours after slaughter, the samples were placed in bag plastic content the liquid ethanol refrigerated at $4{ }^{\circ} \mathrm{C}$ and placed in freezing for 36 hours. The samples were thawed at $4^{\circ} \mathrm{C}$ for 12 hours. The recorded weight differences were expressed as the thawing loss using the following formula:

Thawing loss $\%=[($ weight before thawing - weight after thawing)/weight before thawing] $\times 100$

\section{Statistical analysis}

Data were analyzed using the Statistical Analysis System Program SPSS v.16.0. The model applied included the fixed effects of season. Data given in the tables are means \pm SD. Differences in the mean values of two seasons (one-one) 
were tested by using the independent-samples $T$ test or Mann-Whitney $\mathrm{U}$ test after evaluating normal distribution by the Shapiro-Wilk and Kolmogorov-Smirnov tests. Also, the differences in the mean values of three seasons were analyzed by one-way analysis of variance followed by ANOVA test. The test of the correlation of Pearson-s was used to interpret the relationship between the various studied parameters. A probability level $(p)$ of 0.05 was chosen as the limit for statistical significance in all tests.

\section{RESULTS AND DISCUSSION}

\section{Effect of slaughter season on the different parameters}

The slaughter season did not significantly affect $(p>0.05)$ the $\mathrm{pH}$ and cooking loss results (Table 1). However, the slaughter season significantly affected $(p<0.05)$ electrical conductivity, muscle temperature, drip loss, and thawing loss. All of these parameters were significantly $(p<0.05)$ higher in summer than in winter and/or spring (Table 1).

Slaughter season had no significant effect on the results of $\mathrm{pH}$ measured $90 \mathrm{~min}$ and $48 \mathrm{~h}$. This finding conflicts with the study by Abdelhadi et al. (2012) on the longissimus thoracis muscle of camels, who reported that season significantly affected ultimate $\mathrm{pH}$, with significantly higher values being reported in fall than in winter and summer. In contrast, Arabi et al. (2013) recorded a significant increase in ultimate $\mathrm{pH}$ in summer compared with the levels in winter or fall. Such seasonal differences were attributed by these authors to muscle glycogen stores at the time of slaughtering.

The overall mean of ultimate muscle $\mathrm{pH}(\mathrm{pHu})$ found in this study was in line with the ranges recorded by ElKhasmi et al. (2010) for the longissimus thoracis muscle of camels aged $4-6$ years. However, this value was higher than that reported by Kadim et al. (2006; 2009a; 2016) in the longissimus thoracis muscle of camels at the same age as those in our study. The high $\mathrm{pHu}$ observed in the present results could have been due to a low level of muscle glycogen stores (Kadim et al., 2006; Abdelhadi et al., 2015). The $\mathrm{pHu}$ value of meat is determined by a combination of many factors, including preslaughter handling, postmortem treatment and muscle physiology (Thompson, 2002).

This study found no significant effect of slaughter season on electrical conductivity measured at $90 \mathrm{~min}$. However, the effect of different slaughter seasons on electrical conductivity at $48 \mathrm{~h}$ was significant, with this variable being lower in winter than in summer. This increase in electrical conductivity during the summer may have been due to high ambient temperature having a stimulatory effect on enzyme activity during postmortem glycolysis.

At high temperatures, muscle cell membrane integrity is compromised. Membrane disruption allows the flow of intra- and extracellular fluid, resulting in an increase in electrical conductivity. Completely intact muscle tissue has low electrical conductivity values, which increase with the increase of fluids within the muscle (Byrne et al., 2000). Similarly, Chai et al. (2010) reported that the main reason for the change in electrical conductivity is the movement of electrolytes between the intra-and extracellular compartments.

Very little information is available on the use of electrical conductivity for assessing the quality of camel meat. In contrast, extensive studies have been performed on this issue in different types of meat such as beef (Byrne et al., 2000; Banach and Żywica, 2007; Marenčić et al., 2012) and pork (Lyczyński et al., 2006; Wasilewski et al., 2008; Łyczyński et al., 2009).

Van de Perre et al. (2010) found that season had a significant effect on electrical conductivity of the semimembranosus muscle at $24 \mathrm{~h}$ postmortem in pig. However, these authors reported no significant differences in electrical conductivity values of the gracilis and longissimus dorsi muscles sampled in different seasons.

Table 1: The effect of different seasons on postmortem physical properties of longissimus thoracis muscle of camels.

\begin{tabular}{|c|c|c|c|c|c|}
\hline \multirow[t]{2}{*}{ Parameters } & \multicolumn{3}{|c|}{ Season mean, $n=10$} & \multirow[t]{2}{*}{ Overall mean $\pm S D$} & \multirow{2}{*}{$\begin{array}{c}\text { Effect of season } \\
(p \text {-value })\end{array}$} \\
\hline & Winter & Spring & Summer & & \\
\hline $\mathrm{pH}_{90 \min }$ & 6.9 & 6.8 & 6.9 & $6.9 \pm 0.22$ & 0.427 \\
\hline $\mathrm{pHu}_{48 \mathrm{~h}}$ & 6.0 & 5.8 & 5.8 & $5.9 \pm 0.23$ & 0.110 \\
\hline $\mathrm{EC}_{90 \min }(\mathrm{mS} / \mathrm{cm})$ & 3.3 & 3.4 & 3.2 & $3.3 \pm 1.11$ & 0.958 \\
\hline $\mathrm{ECu}_{48 \mathrm{~h}}(\mathrm{mS} / \mathrm{cm})$ & $5.8^{\mathrm{a}}$ & $7.2^{\mathrm{a}}$ & $8.9^{a b}$ & $7.3 \pm 2.80$ & 0.040 \\
\hline $\mathrm{MT}_{90 \min }\left({ }^{\circ} \mathrm{C}\right)$ & $17.7^{\mathrm{a}}$ & $23.8^{b}$ & $31.0^{c}$ & $24.1 \pm 6.31$ & 0.000 \\
\hline $\mathrm{MTu}_{48 \mathrm{~h}}\left({ }^{\circ} \mathrm{C}\right)$ & $11.0^{\mathrm{a}}$ & $12.1^{\mathrm{a}}$ & $14.5^{\mathrm{b}}$ & $12.5 \pm 2.52$ & 0.003 \\
\hline Drip loss (\%) & $3.9^{\mathrm{a}}$ & $4.4^{\mathrm{a}}$ & $6.0^{\mathrm{ab}}$ & $4.7 \pm 2.02$ & 0.044 \\
\hline Cooking loss (\%) & 30.9 & 33.6 & 35.9 & $33.5 \pm 4.78$ & 0.058 \\
\hline Thawing loss (\%) & $17.8^{\mathrm{a}}$ & $18.5^{a}$ & $23.2^{b}$ & $19.8 \pm 4.67$ & 0.013 \\
\hline
\end{tabular}

EC: electrical conductivity, MT: muscle temperature, SD: standard deviation. Means in the same row are significantly different $(p<0.05)$.

a, b Means with different superscripts within a row are significantly different $(p<0.05)$ 
In contrast, significant effects of different slaughter seasons on muscle temperature at $90 \mathrm{~min}$ and $48 \mathrm{~h}$ after slaughter were observed in our study, with the highest value occurring in summer, rather than in winter or spring. The increase of muscle temperature during summer may be attributable to exposure to heat stress, which represents a stimulus that can increase the rectal temperature of animals. This interpretation was strongly supported by the significant positive correlation between the ambient temperature and rectal temperature values observed in the current study. To our knowledge, no reports have been published about the effect of slaughter season on muscle temperature in camels. However, Nagle et al. (2000) indicated that the exposure of broilers to hot conditions before slaughter $\left(30-35{ }^{\circ} \mathrm{C}\right.$ for $2.5 \mathrm{~h}$ ) significantly affected their muscle temperature at the time of slaughter.

The rates of decline in temperature and $\mathrm{pH}$ during rigor mortis development are probably two of the most important postmortem factors affecting meat quality with respect to color, water-holding capacity, and tenderness (Mancini and Hunt, 2005; Savell et al., 2005; Thompson et al., 2006; Huff-Lonergan and Lonergan, 2007).

In our study, the drip loss was affected by the slaughter season, showing greater values in summer than in winter. Bianchi et al. (2007) reported a similar trend for chicken; specifically, they found higher drip loss in summer than in winter. The decrease of water-holding capacity during summer could be attributed to the high muscle temperature recorded during this season. This finding was in accordance with those of Wang et al. (2009) in broilers, Kim et al. (2012) in cattle, and Warner et al. (2014) in lambs. These previous authors reported that high temperature exposure induces excessive water loss from muscles. The main cause of this decrease in water-holding capacity could have been a decrease in released water, which was presumably caused by meat protein denaturation (Huff-Lonergan and Lonergan, 2005; Visessanguan et al., 2005; Barbut et al., 2008; Bowker and Zhuang, 2015).

High muscle temperature at postmortem accelerates glycolytic rates and $\mathrm{pH}$ decline in muscles, presumably because such conditions stimulate enzymatic activity, which induces excessive denaturation of muscle protein and consequently a decrease of water-holding capacity (Maddock et al., 2005; Bee et al., 2007; Kim et al., 2014). Similarly, many authors have suggested that the combination of high temperature and low $\mathrm{pH}$ during the onset of rigor mortis significantly affects water-holding capacity due to its effects on proteolytic degradation and denaturation of myofibril components (Molette et al., 2003; Alvarado and Sams, 2004; Molette et al., 2006).
The overall mean drip loss in the present study was higher than that reported by Zahedi et al. (2016) for the longissimus thoracis muscle of camels at similar ages.

The non-significant finding on the effect of season on cooking loss observed in our study matched the finding of Suliman et al. (2014). Similar trends were also reported by Chulayo and Muchenje (2013) and Sanchez-Sanchez et al. (2013) in lamb. However, this finding conflicted with the work of Suliman et al. (2016), who found that the loss of camel meat while cooking was significantly higher in summer than in winter and fall.

The result regarding cooking loss in our study could have been due to the more aggressive cooking treatment resulting in the release of both bound and immobilized water, which may have minimized the effect of slaughter season. The overall mean of cooking loss observed in the current study was higher than the values reported by Kadim et al. (2006; 2009a; 2009b; 2016) for the same muscle at the same age. Besides, many factors were previously reported to affect the cooking loss of camel meat, such as age (Kadim et al., 2006; 2008c; 2009a; 2016), degree of marbling and moisture content (Kadim et al., 2006; 2008a; 2008c, 2016), aging (Kadim et al., 2009a), electrical stimulation (Kadim et al., 2009a; 2009b; 2009c), storage time (Suliman et al., 2014; 2016) and muscle type (Kadim et al., 2013; Zahedi et al., 2016).

In the present study, there was a significant increase in thawing loss during summer. This might have been due to a greater loss of water-holding capacity of the muscle protein caused by the high temperature of muscle recorded during this season. The increase in thawing loss is explained by water loss from the muscle due to muscle protein degradation caused by spoilage (Traore et al., 2012). This finding is supported by a previous study by Molette et al. (2006), who found a significant increase in thawing loss of muscles stored at $40{ }^{\circ} \mathrm{C}$ compared with that of muscles stored at $4{ }^{\circ} \mathrm{C}$.

\section{Relationships between the different parameters}

The correlations between all of the measured variables of meat quality reported in Table 2 showed that the $\mathrm{pH}$ at 90 min postmortem had moderate negative correlations, albeit without significance ( $p>0.05$ ), with cooking loss, thawing loss, and muscle temperature $(-0.287<r<-0.038)$ and low positive correlations with $\mathrm{pHu}(r=0.299)$ and drip loss $(r=0.141)$. On the other hand, $\mathrm{pHu}$ was positively correlated with electrical conductivity at $90 \mathrm{~min}(r=0.539$; $p<0.01)$ and negatively correlated with thawing loss $(r=-0.413 ; p<0.05)$.

However, no significant correlation $(p>0.05)$ was observed between the other parameters and muscle $\mathrm{pHu}$. In addition, 
Table 2: Relationship between the different studied parameters

\begin{tabular}{|c|c|c|c|c|c|c|c|c|}
\hline & $\mathrm{pHu}_{48 \mathrm{~h}}$ & $\mathrm{EC}_{90 \text { min }}$ & $\mathrm{ECu}_{48 \mathrm{~h}}$ & $\mathrm{MT}_{90 \mathrm{~min}}$ & $\mathrm{MTu}_{48 \mathrm{~h}}$ & Drip loss & Cooking loss & Thawing loss \\
\hline $\mathrm{pH}_{90 \text { min }}$ & 0.299 & 0.066 & -0.238 & -0.287 & -0.199 & 0.141 & -0.038 & -0.169 \\
\hline $\mathrm{pHu}_{48 \mathrm{~h}}$ & & $0.539^{\star *}$ & 0.081 & -0.270 & -0.156 & 0.082 & 0.076 & $-0.413^{*}$ \\
\hline $\mathrm{EC}_{90 \mathrm{~min}}$ & & & $0.433^{*}$ & -0.015 & $0.370^{*}$ & $0.398^{*}$ & 0.076 & -0.164 \\
\hline $\mathrm{ECu}_{48 \mathrm{~h}}$ & & & & $0.470^{\star *}$ & $0.569^{* *}$ & $0.563^{\star *}$ & $0.615^{\star \star}$ & $0.432^{*}$ \\
\hline $\mathrm{MT}_{90 \mathrm{~min}}$ & & & & & $0.690^{* *}$ & 0.346 & $0.413^{*}$ & $0.580^{* *}$ \\
\hline $\mathrm{MTu}_{48 \mathrm{~h}}$ & & & & & & 0.322 & 0.324 & $0.506^{* *}$ \\
\hline Drip loss & & & & & & & $0.466^{\star *}$ & 0.289 \\
\hline Cooking loss & & & & & & & & $0.468^{\star *}$ \\
\hline
\end{tabular}

EC: electrical conductivity, MT: muscle temperature, ${ }^{*}: p<0.05,{ }^{* *}: p<0.01$. All Pearson correlation coefficients are significant at $p<0.05$.

positive correlation coefficients were found between electrical conductivity at $90 \mathrm{~min}$ and at $48 \mathrm{~h}$ and muscle temperature at $48 \mathrm{~h}$ on the one hand and drip loss on the other $(0.433,0.370$, and 0.398 respectively; $p<0.05)$.

The electrical conductivity at $48 \mathrm{~h}$ after slaughter was positively and significantly correlated with most other meat quality parameters, such as muscle temperature at $90 \mathrm{~min}$ $(r=0.470 ; p<0.01)$, muscle temperature at $48 \mathrm{~h}(r=0.569$; $p<0.01)$, drip loss $(r=0.563 ; p<0.01)$, cooking loss $(r=0.615 ; p<0.01)$, and thawing loss $(r=0.432 ; p<0.05)$. In addition, muscle temperature was positively correlated with cooking loss and thawing loss; moreover, intermediate positive correlations were recorded between cooking loss and other measurements of water-holding capacity such as drip loss $(r=0.466 ; p<0.01)$ and thawing loss $(r=0.468 ; p<0.01)$.

In the present study, the correlations between electrical conductivity and other meat quality parameters were significant when the time after slaughter and maturity of meat increased (Table 2). The significant correlations identified between electrical conductivity at $90 \mathrm{~min}$ and muscle pHu agreed with those reported by Byrne et al. (2000) in studies on beef meat. Similarly, Benaissa et al. (2014) reported a significant positive correlation between the mean values of muscle $\mathrm{pH}$ and electrical conductivity of the longissimus thoracis muscle at different postmortem times in adult dromedary camels. This trend may be attributable to the relationship between electrical properties and glycolytic rate.

In addition, the relationship recorded between electrical conductivity and drip loss was in agreement with that reported in cattle (Byrne et al., 2000), pig (Jůzl et al., 2012), and sheep (Jandasek et al., 2014). The significant relationships found between the previous parameters may have been due to the relationship between electrical properties and water-holding capacity. In fact, the electrical conductivity is a result of various degrees of damage to the cell membrane and the movement of electrolytes between intra-and extracellular compartments during postmortem glycolysis (Byrne et al., 2000; Chai et al., 2010).
Muscle temperature was positively correlated with cooking and thawing loss. This finding agrees with those of Kim et al. (2014), Strydom and Rosenvold (2014), and Warner et al. (2014) who reported that high rigor mortis temperature in carcasses has negative effects on water-holding capacity and color stability, as well as muscle texture. In conflict with our findings, Benaissa et al. (2014) observed a significant positive correlation between muscle temperature and waterholding capacity.

In addition, thawing loss was negatively correlated with pHu. A similar finding was also reported by El-Rammouz et al. (2004) in poultry meat. Moreover, in studies on beef by Abril et al. (2001) and Villarroel et al. (2003) and on broilers by Bowker and Zhuang (2015), it was shown that meat with a higher $\mathrm{pH}$ had greater water-holding capacity than that with a low $\mathrm{pH}$. These observations agree with those reported by Benaissa et al. (2014) in dromedary camel. Indeed, the same authors described a significant positive correlation between the average muscle $\mathrm{pH}$ at different postmortem times and the water-holding capacity of the longissimus thoracis muscle.

Similarly, Huff-Lonergan and Lonergan (2007) reported that, as the $\mathrm{pH}$ of meat reaches the isoelectric point, water loss increases with drip loss. This occurs because $\mathrm{pH}$ has an impact on muscle ultrastructure and on the denaturation state of key muscle proteins. Protein solubility is at its lowest if muscle $\mathrm{pH}$ is at or near its isoelectric point and then reaches a net charge near zero, which is associated with the loss of the ability to attract and bind water.

However, no correlation between $\mathrm{pHu}$ and cooking loss was found in our study, whereas correlations were recorded between cooking loss and other measurements of waterholding capacity such as drip loss and thawing loss, which indicate moisture loss from the same reservoir, namely, free water from the sarcoplasm. Although significant, these relationships showed intermediate correlations. It is likely that, in our experimental cooking conditions, the effect of pHu on cooking loss was attenuated. 


\section{CONCLUSION}

In the camel, slaughter season had a significant effect on several postmortem metabolic parameters of muscle, due to its effect on electrical conductivity, muscle temperature, drip loss and thawing loss. So, this effect was higher in summer than in winter and/or spring seasons. The study also indicated that late postmortem electrical conductivity was better than muscle $\mathrm{pH}$ measurement and it can be employed in practice for diagnosis of camel's meat quality.

\section{ACKNOWLEDGEMENTS}

The authors are very much thankful to the staff of El Oued municipality slaughterhouse especially the veterinary inspectors for the help to carry out this research. We also thank Mr. Khalifa Hamad for assisting in meat sample collections. My sincere thanks go to the staff of the Laboratory of Hygiene and Animal Pathology, at the Institute of Veterinary Sciences, Ibn Khaldoun University of Tiaret, Algeria.

\section{AUTHOR'S CONTRIBUTIONS}

B. Hamad conducted the study. H. Aggad designed the study and served as principal supervisor. L. Hadef searched for the literatures and participated in manuscript writing. A. Beddada contributed to collect meat samples, B. Faye revised the manuscript.

\section{REFERENCES}

Abdelhadi, O. A. M., S. A. Babiker, D. Bauchart, A. Listrat, D. Rémond, J. F. Hocquette and B. Faye. 2015. Effect of gender on quality and nutritive value of dromedary camel (Camelus dromedarius) Longissimus lumborum muscle. J. Saudi Soc. Agric. Sci. 16: 242-249.

Abdelhadi, O. A. M., S. A. Babiker, B. Picard, C. Jurie, R. Jailler, J. F. Hocquette and B. Faye. 2012. Effect of season on contractile and metabolic properties of desert camel muscle (Camelus dromedarius). Meat Sci. 90: 139-144.

Abril, M., M. M. Campo, C. O. Sańudo, P. Alberti and A. I. Negueruela. 2001. Beef colour evolution as a function of ultimate $\mathrm{pH}$. Meat Sci. 58: 69-78.

Alvarado, C. Z. and A. R. Sams. 2004. Turkey carcass chilling and protein denaturation in the development of pale, soft and exudative meat. Poult. Sci. 83: 1039-1046.

Arabi, O. H., S. F. Elmawlla, E. Abdelhai and A. Elhadi. 2013. The effects of seasons, age of the animal and storage time on physical properites of camel's meat (Camelus dromedaries). Gezira J. Eng. Appl. Sci. 8: 17-30.

Banach, J. K. and R. Żywica. 2007. Usability of beef conductivity properties for assessment and control of its ripeness. Pol. J. Food Nutr. Sci. 57: 25-28.

Barbut, S., A. A. Sosnicki, S. M. Lonergan, T. Knapp, D. C. Ciobanu, L. J. Gatcliffe, E. Huff-Lonergan and E. W. Wilson. 2008.
Progress in reducing the pale, soft and exudative (PSE) problem in pork and poultry meat. Meat Sci. 79: 46-63.

Bee, G., A. L. Anderson, S. M. Lonergan and E. Huff-Lonergan. 2007. Rate and extent of $\mathrm{pH}$ decline affect proteolysis of cytoskeletal proteins and water-holding capacity in pork. Meat Sci. 79: 359-365.

Benaissa, A., A. Ould El-Hadj-Khelil, A. Adamou, B. Babelhadj, M. Mehirig, B. Boufaghes, M. Attoussi, H. Samili and S. Becila. 2014. Qualité de la viande de dromadaire dans les abattoirs de Ouargla en Algérie. I. Quelques caractéristiques physicochimiques de la viande au cours de la maturation. Rev. Elev. Med. Vet. Pays Trop. 67: 223-228.

Bianchi, M., M. Petracci, F. Sirri, E. Folegatti, A. Franchini and A. Meluzzi. 2007. The influence of the season and market class of broiler chickens on breast meat quality traits. Poult. Sci. 86: 959-963.

Bowker, B. and H. Zhuang. 2015. Relationship between water-holding capacity and protein denaturation in broiler breast meat. Poult. Sci. 94: 1657-1664.

Byrne, C. E., D. J. Troy and D. J. Buckley. 2000. Postmortem changes in muscle electrical properties of bovine $M$. longissimus dorsi and their relationship to meat quality attributes and $\mathrm{pH}$ fall. Meat Sci. 54: 23-34.

Chai, J., Q. Xiong, C. X. Zhang, W. Miao, F. E. Li, R. Zheng, J. Peng and S. W. Jiang. 2010. Effect of pre-slaughter transport plant on blood constituents and meat quality in halothane genotype of NN Large WhitexLand race pigs. Livest. Sci. 127: 211-217.

Chulayo, A. Y. and V. Muchenje. 2013. The effects of pre-slaughter stress and season on the activity of plasma creatine kinase and mutton quality from different sheep breeds slaughtered at a smallholder abattoir. Asian Aust. J. Anim. Sci. 26: 1762-1772.

Correa, J. A., H. Gonyou, S. Torrey, T. Widowski, R. Bergeron, T. Crowe, J. P. Laforest and L. Faucitano. 2014. Welfare of pigs being transported over long distances using a pot-belly trailer during winter and summer. Animals. 4: 200-213.

D'alessandro, A. G., G. Maiorano, M. Ragni, D. Casamassima, G. Marsico and G. Martemucci. 2013. Effects of age and season of slaughter on meat production of light lambs: Carcass characteristics and meat quality of leccese breed. Small Rum. Res. 114: 97-104.

El-Khasmi, M., F. Riad, A. Safwate, E. Tahri, M. Farh, N. El Abbadi, V. Coxam and B. Faye. 2010. Effects of preslaughter stress on meat quality and phosphocalcic metabolism in camels (Camelus dromedarius). J. Camelid Sci. 3: 33-38.

El-Rammouz, R., R. Babile'and X. Fernandez. 2004. Effect of ultimate $\mathrm{pH}$ on the physicochemical and biochemical characteristics of turkey breast muscle showing normal rate of postmortem $\mathrm{pH}$ Fall. Poult. Sci. 83: 1750-1757.

Franco, D., E. Rodríguez, L. Purriños, S. Crecente, R. Bermúdez and J. M. Lorenzo. 2011. Meat quality of "Galician Mountain" foals breed. Effect of sex, slaughter age and livestock production system. Meat Sci. 88: 292-298.

Honikel, K.O. 1998. Reference methods for the assessment of physical characteristics of meat. Meat Sci. 49: 447-457.

Honkavaara, M., E. Rintasalo, J. Ylonen and T. Pudas. 2003. Meat quality and transport stress of cattle. Dtsch. Tierarztl. Wochenschr. 110: 125-128.

Huff-Lonergan, E. and S. M. Lonergan. 2005. Mechanisms of waterholding capacity of meat: The role of postmortem biochemical and structural changes. Meat Sci. 71: 194-204.

Huff-Lonergan, E. and S. M. Lonergan. 2007. New frontiers in understanding drip loss in pork: Recent insights on the role of postmortem muscle biochemistry. J. Anim. Breed. Genet. 124: 19-26. 
Jandasek, J., M. Milerski and M. Lichovnikova. 2014. Effect of sire breed on physico-chemical and sensory characteristics of lamb meat. Meat Sci. 96: 88-93.

Jůzl, M., H. Šulcerová, T. Gregor, T. Urban, P. Sláma, P. Chalupová, T. Sedláčková, K. Kaplanová and F. Weisz. 2012. The relationship between colour and other meat quality traits in Czech Large White pigs. Maso Int. J. Food Sci. Technol. 2: 131-136.

Kadim, I. T. 2013. A review of the nutritive value and meat quality characteristics of the dromedary (Camelus dromedaries) camel meats. Camel. 1: 129-156.

Kadim, I. T., M. R. Al-Ani, R. S. Al-Maqbaly, M. H. Mansour, O. Mahgoub and E. H. Johnson. 2011. Proximate, amino acid, fatty acid and mineral composition of raw and cooked camel (Camelus dromedarius) meat. Br. Food J. 113: 482-493.

Kadim, I. T., A. A. Abdulbari and R. H. Muhssin. 2016. Effect Age and cooking on quality characteristics and nutritive value of camel (Camelus Dromedaries) Longissimus thoraces muscle. J. Med. Sci. Clin. Res. 4: 9748-9757.

Kadim, I. T., Y. Al-Hosni, O. Mahgoub, W. Al-Marzooqi, S. K. Khalaf, S. S. H. Al-Sinawi, A. M. Al-Lawati and I. S. Al-Amri. 2009a. Effect of low voltage electrical stimulation on post mortem biochemical and quality characteristics of Longissimus thoracis muscle from one-humped camel (Camelus dromedarius). Meat Sci. 82: 77-85.

Kadim, I. T., A. Al-Karousi, O. Mahgoub, W. Al-Marzooqi, S. K. Khalaf, R. Al-Maqbaly, S. S. H. Al-Sinani and G. Raymbek. 2013. Chemical composition, quality and histology characteristics of individual dromedary camel (Camelus dromedaries) muscles. Meat Sci. 93: 564-571.

Kadim, I. T., O. Mahgoub and W. Al-Marzooqi. 2008a. Meat quality and composition of Longissimus thoracis from Arabian camel (Camelus dromedarius) and Omani beef: A comparative study. J. Camelid Sci. 1: 37-47.

Kadim, I. T., O. Mahgoub, W. Al-Marzooqi, D. S. Al-Ajmi, R. S. AlMaqbali and S. M. Al-Lawati. 2008b. The influence of seasonal temperatures on meat quality characteristics of hot-boned, $M$. psoas major and minor, from goats and sheep. Meat Sci. 80: 210-215.

Kadim, I. T., O. Mahgoub, W. Al-Marzooqi, S. Al-Zadijali, K. Annamalai and M. H. Mansour. 2006. Effects of age on composition and quality of muscle Longissimus thoracis of the Omani Arabian camel (Camelus dromedaries). Meat Sci. 73: 619-625.

Kadim, I. T., O. Mahgoub, W. Al-Marzooqi and S. K. Khalaf. 2009b. Effect of low voltage electrical stimulation and splitting carcass on histochemical and meat quality characteristics of the onehumped camel (Camelus dromedarius) Longissimus thoracis muscle. J. Camelid Sci. 2: 30-40.

Kadim, I. T., O. Mahgoub, W. Al-Marzooqi, S. K. Khalaf, M. H. Mansour, S. S. H. Al-Sinawi and I. S. Al-Amri. 2009c. Effect of electrical stimulation on histochemical muscle fibre staining, quality and composition of camel and cattle Longissimus thoracis muscles. J. Food Sci. 74: S44-S52.

Kadim, I. T., O. Mahgoub and M. Mbaga. 2014. Potential of camel meat as a nontraditional high quality source of protein for human consumption. Anim. Front. 4: 13-17.

Kadim, I. T., O. Mahgoub and R. W. Purchas. 2008c. A review of the growth, and of the carcass and meat quality characteristics of the one-humped camel (Camelus dromedaries). Meat Sci. 80: 555-569.

Kim, Y. H. B., A. Stuart, G. Nygaard and K. Rosenvold. 2012. High pre rigor temperature limits the ageing potential of beef that is not completely overcome by electrical stimulation and muscle restraining. Meat Sci. 91: 62-68.
Kim, Y. H. B., R. D. Warner and K. Rosenvold. 2014. Influence of high pre-rigor temperature and fast $\mathrm{pH}$ fall on muscle proteins and meat quality. Anim. Prod. Sci. 54: 375-395.

Łyczyński, A., G. Runowska, E. Pospiech, M. Koćwin-Podsiadła, J. Wojtczak, E. Rzosińska, B. Grześ, B. Mikołajczak and E. Iwańska. 2009. Estimation of selected porcine meat quality indicators on the basis of electrical conductivity measured 24 hours post-slaughter. Anim. Sci. Pap. Rep. 27: 51-58.

Łyczyński, A., S. Wajda, G. Czyżak-Runowska, E. Rzosińska and B. Grześ. 2006. Effect of environmental conditions on pork meat quality. Pol. J. Food Nutr. Sci. 15/56: 109-116.

Maddock, K. R., E. Huff-Lonergan, L. J. Rowe and S. M. Lonergan. 2005. Effect of $\mathrm{pH}$ and ionic strength on $\mu$-and m-calpain inhibition by calpastatin. J. Anim. Sci. 83: 1370-1376.

Mancini, R. A. and M. C. Hunt. 2005. Current research in meat color. Meat Sci. 71: 100-121.

Maqsood, S., A. Abushelaib, K. Manheem and I. T. Kadim. 2015. Characterisation of the lipid and protein fraction of fresh camel meat and the associated changes during refrigerated storage. J. Food Compos. Anal. 41: 212-220.

Marenčić, D., A. Ivanković, V. Pintić, N. Kelava and T. Jakopović 2012. Effect of the transport duration time and season on some physicochemical properties of beef meat. Arch. Tierzucht. 55: 123-131.

María, G. A., T. Buil, G. Liste, M. Villarroel, C. Sañudo and J. L. Olleta. 2006. Effects of transport time and season on aspects of rabbit meat quality. Meat Sci. 72: 773-777.

Miranda, D.L.L.G., M. Villarroel, J. L. Olleta, S. Alierta, C. Sañudo and G. A. Maria. 2009. Effect of the pre-slaughter logistic chain on meat quality of lambs. Meat Sci. 83: 604-609.

Molette, C., H. Rémignon and R. Babilé. 2003. Maintaining muscles at a high post-mortem temperature induces PSE like meat in turkey. Meat Sci. 63: 525-532.

Molette, C., V. Sérieye, M. Rossignol, R. Babilé, X. Fernandez and H. Rémignon. 2006. High postmortem temperature in muscle has very similar consequences in two Turkey genetic lines. Poult. Sci. 85: 2270-2277.

Nagle, T. A., N. G. Gregory and T. E. Lowe. 2000. Effect of Preslaughter Heat Stress, Exercise or Adrenaline Injection on Post-mortem Heat-stable Pinkness, Textureand Water Holding Capacity in Chicken. In: Proceedings of the $46^{\text {th }}$ International Congress of Meat Science and Technology, Finland, pp. 146-147.

Raiymbeck, G., I. Kadim, G. Konuspayeva, O. Mahgoub, A. Serikbayeva and B. Faye. 2015. Discriminant amino-acid components of Bactrian (Camelus bactrianus) and dromedary (Camelus dromedarius) meat. J. Food Compos. Anal. 41: 194-200.

Sanchez-Sanchez, M., C. Vieira-Aller, J. De-La-Fuente-Vazquez, C. Perez-Marcos, S. Lauzurica-Gomez, E. Gonzalez-De-Chavarri and M. T. Diaz-Diaz-Chiron. 2013. Effect of season and stocking density during transport on carcass and meat quality of suckling lambs. Span. J. Agric. Res. 11: 394-404.

Savell, J. W., S. L. Mueller and B. E. Baird. 2005. The chilling of carcasses. Meat Sci. 70: 449-459.

Strydom, P. E. and K. Rosenvold. 2014. Muscle metabolism in sheep and cattle in relation to high rigor temperature-overview and perspective. Anim. Prod. Sci. 54: 510-518

Suliman, A. M. E., S. A. Fadlalmola, A. S. E. Babiker, O. A. Arabi and S. M. Ibrahim. 2014. The effect of season, age and preservation on camel meat sausage. Food and Public Health. 4: 293-300.

Suliman, A. M. E., S. A. Fadlalmola, A. S. A. Babiker, H. S. Yousif, S. M. Ibrahim, Y. M. Abdelrahim and O. A. Arabi. 2016. Influence of season and storage period of camel meat on the quality characteristics of 
burger. J. Food Nutr Disor. 5: 1.

Thompson, J. 2002. Managing meat tenderness. Meat Sci. 62: 295-308.

Thompson, J. M., D. Perry, B. Daly, G. E. Gardner, D. J. Johnston and D. W. Pethick. 2006. Genetic and environmental effects on the muscle structure response post-mortem. Meat Sci. 74: 59-65.

Traore, S., L. Aubry, P. Gatellier, W. Przybylski, D. Jaworska, K. Kajak-Siemaszko and V. Santé-Lhoutellier. 2012. Higher drip loss is associated with protein oxidation. Meat Sci. 90: 917-924.

Van de Perre, V., A. Ceustermans, J. Leyten and R. Geers. 2010. The prevalence of PSE characteristics in pork and cooked ham-effects of season and lairage time. Meat Sci. 86: 391-397.

Villarroel, M., G. A. Maria, C. Sańudo, J. L. Olleta and G. Gebresenbet. 2003. Effect of transport time on sensorial aspects of beef meat quality. Meat Sci. 63: 353-357.

Visessanguan, W., S. Benjakul, A. Panya, C. Kittikun and A. Assavanig. 2005. Influence of minced pork and rind ratios on physico-chemical and sensory quality of Nham-a Thai fermented pork sausage. Meat Sci. 69: 355-362.

Wang, R. R., X. J. Pan and Z. Q. Peng. 2009. Effects of heat exposure on muscle oxidation and protein functionalities of Pectoralis majors in broilers. Poult. Sci. 88: 1078-1084.

Warner, R. D., M. Kerr, Y. H. B. Kim and G. Geesink. 2014. Pre-rigor carcass stretching counteracts the negative effects of high rigor temperature on tenderness and water holding capacity-using lamb muscles as a model. Anim. Prod. Sci. 54: 494-503.

Wasilewski, P. D., J. Nowachowicz, G. Michalska, B. Lynch and A. M. Mullen. 2008. Electric conductivity of Longissimus dorsi muscle of pigs fed the fodder with addition of conjugated linoleic acid. J. Cent. Eur. Agric. 9: 665-668.

Węglarz, A. 2010. Meat quality defined based on $\mathrm{pH}$ and colour depending on cattle category and slaughter season. Czech J. Anim. Sci. 55: 548-556.

Zahedi, Y., M. J. Varidi and M. Varidi. 2016. Proteome changes in Biceps femoris muscle of Iranian one-humped camel and their effect on meat quality traits. Food Technol. Biotechnol. 54: 324-334. 